\title{
Stage IIC Merkel Cell Carcinoma AJCC v7
}

National Cancer Institute

\section{Source}

National Cancer Institute. Stage IIC Merkel Cell Carcinoma A/CC v7. NCI Thesaurus. Code C85896.

Stage IIC includes: T4, N0, M0. T4: Primary tumor invades bone, muscle, fascia, or cartilage. NO: No regional lymph node metastasis. MO: No distant metastasis. (AJCC 7th Ed.) 